\title{
The Southern Dutch Dialect Dictionaries
}

\author{
Joep Kruijsen, co-editor of the Woordenboek van de Limburgse Dialecten, \\ University of Nijmegen and \\ Jacques van Keymeulen, co-editor of the Woordenboek van \\ de Vlaamse Dialecten, University of Ghent
}

\begin{abstract}
The article on the three dictionaries of the southern Dutch dialects is divided into two parts. In the first part Joep Kruijsen (University of Nijmegen, The Netherlands) treats the history of the Woordenboek van de Brabantse Dialecten (Dictionary of the Brabant Dialects), the Woordenboek van de Limburgse Dialecten (Dictionary of the Limburg Dialects) and the Woordenboek van de Vlaamse Dialecten (Dictionary of the Flemish Dialects), three dictionaries which together record the vocabulary of the southern Dutch dialects. He describes the plan and method of collection and presentation. Because of the systematic arrangement (introduced by Weijnen) the three dictionaries are unique in Dutch and international lexicography. They combine a dictionary with a word atlas.

In the second part of the article Jacques van Keymeulen (University of Ghent, Belgium) deals with a number of new methodological developments which were introduced following the start of the publication of part III General Vocabulary (apart from Part I Agricultural Terminology and Part II Nonagricultural Terminologies). After the institution of REWO (Regionale Woordenboeken), a coordinating body for the three dictionaries within the Dutch Language Union, and because of the introduction of sophisticated software, the databases can be combined to give a survey of the whole of the southern Dutch language area.
\end{abstract}

Keywords: LEXICOGRAPHY, ONOMASTOLOGY, DIALECT GEOGRAPHY, LANGUAGE VARIATION, PHONOLOGY, HISTORICAL LINGUISTICS, DICTIONARY, REGIONAL DICTIONARY, WORD ATLAS, CARTOGRAPHY, GENERAL VOCABULARY, AGRARIAN TERMINOLOGY, TERMINOLOGY OF TRADITIONAL CRAFTS, DIALECT, TRADITIONAL DIALECT, FLEMISH, BRABANT DIALECT, LIMBURG DIALECT, DUTCH, THE NETHERLANDS, BELGIUM, FRENCH FLANDERS, METHODOLOGY, SYSTEMATICAL ARRANGEMENT, AUTOMATION, DATABASE, USER GROUPS, USEFULNESS

Samenvatting: Dialectwoordenboeken van het zuidelijke Nederlands. Het artikel over de drie dialectwoordenboeken van het zuidelijke Nederlands valt uiteen in twee delen. In een eerste deel heeft Joep Kruijsen (Katholieke Universiteit Nijmegen, Nederland) het over de ontstaansgeschiedenis van het Woordenboek van de Brabantse Dialecten, het Woordenboek van de Limburgse Dialecten en het Woordenboek van de Vlaamse Dialecten, drie woordenboeken die samen de woordenschat van de zuidelijk-Nederlandse dialecten beschrijven. Hij schetst opzet en methode van verzamelen en presenteren. Door het systematische ordeningsprincipe (geintroduceerd door Weijnen) nemen de woordenboeken een unieke plaats in in de Nederlandse en internationale dialectlexicografie. Ze zijn een combinatie van een woordenboek en een woordatlas. 
In een tweede deel heeft Jacques van Keymeulen (Universiteit Gent, België) het over een aantal methodologische vernieuwingen die naar aanleiding van het begin van de publicatie van deel III Algemene Woordenschat (naast deel I Landbouwwoordenschat en deel II Niet-agrarische Vaktalen) werden geintroduceerd. Door de installatie van het overlegorgaan REWO (Regionale Woordenboeken) binnen de Nederlandse Taalunie en door de introductie van gesofistikeerde software kunnen de gegevens van de drie databases samengevoegd worden tot overzichten voor het hele zuidelijk-Nederlandse taalgebied.

Sleutelwoorden: LEXICOGRAFIE, ONOMASIOLOGIE, DIALECTGEOGRAFIE, TAALVARIATIE, FONOLOGIE, HISTORISCHE TAALKUNDE, WOORDENBOEK, REGIONAAL WOORDENBOEK, WOORDATLAS, CARTOGRAFIE, ALGEMENE WOORDENSCHAT, AGRARISCHE TERMINOLOGIE, TRADITIONELE VAKTERMINOLOGE, DIALECT, TRADITIONEEL DIALECT, VLAAMS, BRABANTS, LIMBURGS, NEDERLANDS, NEDERLAND, BELGIË, FRANS-VLAANDEREN, METHODOLOGIE, SYSTEMATISCHE ORDENING, AUTOMATISERING, DATABASE, GEBRUIKERSGROEPEN, BRUIKBAARHEID

\section{THREE LEXICOGRAPHICAL PROJECTS}

\section{The origin of the southern Dutch dictionaries}

In 1958 Toon Weijnen took over the chair of Dutch and Indo-European Linguistics at the Nijmegen Faculty of Arts. Weijnen was more or less the personification of research on the Brabant dialects and at that moment he must already have had very explicit ideas on at least one of his later projects. The roots of the Woordenboek van de Brabantse Dialecten (Dictionary of the Brabant Dialects) lie in the enquiries that he himself had undertaken in the thirties and that in 1937 resulted in a Ph.D. dissertation on dialect borders in Brabant. The dissertation was written under the supervision of Jacques van Ginneken. Between 1937 and 1958 he published many books and articles on lexical and phonological topics in the Brabant dialects in the Netherlands and in Belgium. Very often Weijnen looked at the neighbouring dialects of Zeeland and Limburg for elucidatory facts. Just as the Leiden specialists under Kloeke were primarily oriented towards the role of the dialects of Holland in the Dutch language area and as Heeroma in Groningen started his observations on Dutch in Lower Saxony, so the starting-point for Weijnen's Dutch philology was to be found in the dialectological situation in Brabant. This special interest of his has been noticeable in all his later work, whether in Dutch or in European dialectology.

In 1960 the Netherlands Organisation for Pure Research made it possible to start new fieldwork in Brabant. Jan van Bakel became involved in the project; written enquiries were started and within five years the project developed into a real institution, the Nijmeegse Centrale voor Dialect- en Naamkunde (NCDN). In 1967 the "Preliminary Introduction" of the Woordenboek van de Brabantse Dialecten (WBD) appeared, together with the first fascicle on "the farm". 
In the meantime, at the beginning of the sixties, preparations for the Woordenboek van de Limburgse Dialecten (WLD) started as well. The first impetus for the Limburg project was research by means of an extended questionnaire, undertaken in 1914 by Schrijnen and Van Ginneken, together with the school inspector Verbeeten. Schrijnen and Van Ginneken were later appointed professors in Nijmegen. They collected, by correspondence, a large amount of precious dialect material at about 90 localities in Limburg. At the beginning of the thirties the folklorist Winand Roukens expounded a plan for a dictionary of the Limburg dialects in the journal Veldeke. He contacted the dialect centre of the University of Leuven where Grootaers and Pauwels were making recordings of the dialects in the Belgian province of Limburg. To Roukens we owe the idea of a dictionary of Limburg dialects, covering the two provinces of Limburg in Belgium and in the Netherlands.

The final step towards the realisation of this Limburg dictionary does not come from Roukens though, but from Weijnen. The Brabant dictionary had made a good start and Weijnen had a central role in the Faculty of Arts of the University of Nijmegen. Therefore he was in a good position to realise the Limburg pendant of the Brabant dictionary. Frans Peters and later Pieter Goossens gathered an enormous amount of new data on the Limburg dialects. In the beginning they were financed by the Netherlands Organisation for Pure Research and later by the faculty itself. They also received a copy of a similarly extensive amount of data on the agricultural lexicon, collected orally by Jan Goossens in Belgian Limburg. In 1983 the first fascicle, with an introduction, appeared. At about the same time the cultural departments of the provincial governments decided to participate in the project, first in the Netherlands, later in Belgium too.

Well over ten years later than Weijnen, Willem Pée started the preparation of the Woordenboek van de Vlaamse Dialecten (WVD) at the University of Ghent. Pée was inspired by the two projects of Weijnen with regard to the plan and the microstructure of the Flemish dictionary. This dictionary is issued in two parallel publications. A "scientific text" which contains entry forms, phonetic data and place code numbers for every article, is meant for specialists. The parallel "dictionary text" aimed at the general public, is based on the mapping of the data in the scientific text. In the dictionary text the information of the scientific text is rewritten in a globalised form; place code numbers are replaced by indications with regard to frequency and region. In 1979 the introduction and the first fascicle appeared. With this project the whole southern Dutch language area is covered by dictionaries with the same lexicographical approach (see Annex A for the map).

In 1990, the Dutch Language Union (Nederlandse Taalunie), which fosters linguistic cooperation between the Netherlands and Belgium, instituted a coordinating committee for the regional dictionaries covering the two countries. Around this time the Belgian provinces involved in the two Nijmegen projects made the appointment of two editors for these projects possible at the 
University of Leuven. Within the framework of the Dutch Language Union the three projects, in Nijmegen, Leuven and Ghent are coordinated more and more. This is important, as work on the so-called general part of the lexicon is about to begin. There will be a common database, fed by the three projects. It has also been agreed upon that three or four editors for each dictionary will try to finish the general lexicon within the foreseeable future.

\section{Methods of collecting and treating the data}

What do the dictionaries look like, what do they describe and how is it done? Three matters have to be raised in this respect: the material treated, the systematic design, i.e. the macrostructure of the dictionaries, and the organisation of the articles, i.e. the microstructure of the dictionaries.

\section{$2.1 \quad$ The data}

The dictionaries take stock of the lexicons of the dialects in the regions involved. Dialects are geographically differentiated diasystems.

In the second half of the twentieth century the use of dialects is restricted to certain social classes, though different for each region, and to specific situations. The traditional dialect lexicon described here is to be conceived as the relatively stable, natural colloquial language of the majority of the language community in the first half of this century. The oldest generation still has knowledge of this standard. In the course of the second half of this century this traditional dialect-vocabulary has become an historical one. The dialect dictionaries are to be seen as historical dictionaries of a special kind: they record an actual lexicon by describing almost exclusively the knowledge, not the usage of a language.

Knowledge or usage, the situation differs from region to region. In the Netherlands use of the traditional dialect occurs only together with the standard language. This has already been the case for two generations. Knowledge of the dialect is still to be found among the oldest generation, among the middle generation it is already rare. In the Dutch province of Brabant, Northem Brabant, the use of dialect is restricted to very specific situations and here too, it is in danger of becoming a regiolect, a variety between standard and dialect without the relative stability of the traditional dialects. In Limburg, especially in the south, the use and a fortiori the knowledge of dialects, is more widespread and accepted than in Brabant, but here too the pressure of the standard language in situations beyond regional issues is high.

In Belgium the position of the dialect differs from that in the Netherlands. The Dutch standard language has gained prestige during the last hundred 
years. Adoption of the (northern) standard language was and still is not a matter of course. The emancipatory language conflict was not only directed against French as the dominating language, but also against dialects that were thought to keep the Flemish people from speaking the (northern) standard language correctly. This antidialect attitude is still noticeable. In the Netherlands, Brabant and Limburg dialects are still held in esteem, whereas in Belgium, the appreciation of dialects is only growing slowly.

In French Flanders and in the north-eastern part of the province of Liège, the situation of the Dutch dialects is even more complicated. In the northernmost part of France, the Dutch standard language disappeared three centuries ago. The only variety of Dutch which speakers from this area understand, is their own dialect; they have no knowledge of standard Dutch any more. In the province of Liège, between Voeren (Furon) and Eupen, this situation has now existed for two centuries. Dutch dialect speakers are wedged in between speakers of the dominant French language and the neighbouring German language. Here too Dutch is unknown as a written language. In these two areas the alarm for the Dutch dialects should be sounded.

\subsection{The macrostructure, systematic ordering in three parts}

One of the most salient features of the three southern Dutch dictionaries is the nonalphabetical ordering of the entries; they are presented in systematic order, by word-field, or rather (because word-field should suggest a semantic ordering) by the field in which they are used. They are arranged according to activities and objects around a certain occupation, such as work in the fields, flailing, cooperage or mining, the names of birds, etc.

At the beginning of the sixties, a theoretical discussion on the most suitable ordering of the lexicon of a large and internally differentiated area was conducted in dialect lexicography. Weijnen and Van Bakel often argued in favour of abandoning the formal criterion of the written word, i.e. the graphic registration of speech in dialect lexicographic work. Yet the publication in 1967 of the first fascicle of the dictionary without an alphabetical ordering was regarded as something new. No doubt, practical reasons influenced this choice to have it processed completely. It was no longer necessary to collect all the data, and to start with the treatment of $A$ words before the first fascicle could be published. The dictionary-user will find all words concerning a specific field concentrated in one place. In an alphabetical dictionary, however, the dictionary-user will have to glean the sought-for information from diverse entries.

Alphabetical indexes on keywords in a fascicle and cumulative indexes for a volume make it possible to consult the material in other ways, e.g. by wordform, in order to get an idea of the polysemy of a given word.

By ordering the dictionaries in such a systematic way, Weijnen and Van Bakel joined the geolinguistic rather than the lexicographic tradition. The Ley- 
den linguistic atlas treated limited word-fields and also the French regional atlases were ordered according to word-fields. In the southern Dutch dictionaries the geolinguistic design of the language map and atlas on which the geographically scattered heteronyms of a concept are given, is combined with the completeness of a dictionary. Because the areas covered by the three dictionaries are rather extensive, the number of heteronyms for a concept can be high. For a concrete and familiar object like a scoop-shovel no less than seven heteronyms are found in the Limburg dialects, each with its own geographical area. For the names of plants or animals this number will be much higher. The question for a dictionary like the one under discussion will not be whether a word like eren in the meaning of "to plough" (from Lat. arare) exists in southern Dutch dialects, but rather which geographical position the word eren takes among other words for "to plough" and what the dialectal pronunciation of this word is.

An article in the dictionary gives all current words for a certain concept in one of the three areas, together with their pronunciation and their location. The order of the concepts is as close as possible to the reality of the dialect-speaker. It is obvious that word-fields can be ordered in more than one way. The concept "clover" could be treated as part of the plant-names in the general vocabulary, as part of the section on crops in the volume on agriculture, or as part of the section on fodder in the volume on cattle breeding. The editor makes the final choice and provides the necessary references, but this will be influenced by the field which the dialect-speaker himself assigns to the word.

The general division of the dictionaries is based on the thematic ordering according to fields.

Each regional dictionary consists of three parts, and each part of a series of fascicles in which a separate item is dealt with. Roughly speaking, each part will comprise about 2,000 pages.

The first two parts treat the vocabulary related to occupations. Part I deals with the agricultural vocabulary. Until the middle of this century, the greater part of the dialect-speaking population was active in agriculture. Part II covers other technical and craft terminologies: those of the baker and the butcher, of the brewer and the miller, the miner and the textile-worker, etc. Part III contains the general vocabulary (i.e. the lexicon which is not sociologically bound), supposed to be generally known among the dialect-speaking community. It includes the terminology of social life, of education, administration and religion, household words for clothing, cleaning, cooking, the names of plants and animals, of health and hygiene. The so-called closed word categories (adverbs, prepositions, conjunctions, etc.) will also be dealt with here.

\subsection{The microstructure: the article}

Representativeness and verifiability of the data become visible in the article itself, i.e. in the microstructure of a dictionary. All possible sources have been 
described and are well-documented in the introductions. These sources consist in the first place of the enquiries made by the editors themselves. During the past 30 years approximately 200 correspondents of the institute in Nijmegen had more than 100 questionnaires completed by dialect spokespersons both in Brabant and Limburg. The data from these questionnaires was supplemented by other sources: lists from other dialect institutes, direct oral enquiries by the editors, local dictionaries and monographs, theses, etc. The collection of data is as complete as possible. Not only familiar articles are mentioned, but also those with mainly documentary value. Another keyword is precision: precision in phonetic documentation and precision in localisation. Many linguistic maps are inserted in the fascicles to give a clear view of the latter.

Thus an article consists of:

- the title of the article, i.e. the keyword or the description of the concept to which it is easy to refer, e.g. scoop-shovel.

- the acknowledgement of the sources: questionnaires and monographs or other sources consulted.

- the elucidation of the title: the keyword is explained; the connection with other articles is often underlined. Special notes of informants are reported, encyclopedic peculiarities of a concept in a technical language can be given. In the example of the scoop-shovel an illustration is inserted, details about its use are given, etc.

- the corpus of the article containing all the heteronyms, the terms given for the concept enquired about: a possibly constructed Dutch (or Dutchified) reference form and the phonetic variants noted down as exactly as possible. For each variant the exact geographical location is given by means of place-codes, often visually presented in the form of a map. This applies to parts I and II of the Brabant and Limburg projects in Nijmegen; the Flemish dictionary in Ghent presents its geographical information in a slightly different way, as can be seen in the annexes.

\section{The usefulness of dialect dictionaries}

In what ways is such an extensive description of language useful?

The traditional dialect lexicon is disappearing fast and is in some regions, as we have seen, present in the memory of the oldest generation only. The collection of this lexicon therefore has a high priority. In spite of this fact, appeals like "save the dialects" or "preserve before it is too late" are dangerous and biased. These phrases could lead to the misunderstanding that the lexicographer nostalgically interests himself in an older and purer and therefore more highly esteemed language variety. On the contrary, he/she is interested in a rapid registration of a historical group of words and meanings, a vocabulary belonging to a society that has already disappeared. 
The usefulness of dialectal dictionaries can be indicated as follows:

(a) Such regional dialect dictionaries are linguistically useful, because they uncover part of the linguistic reality. The oral enquiries often make it possible to note down subtle distinctions in phonetic variations (as in $W B D$ and $W L D$ ), but the main linguistic importance undoubtedly lies in the semantic and etymological domains. The dictionaries present the possibility to study fields of words and meanings onomasiologically and semasiologically and to trace the history of the distribution of wordforms and meanings.

Weijnen himself has always stressed the importance of the study of dialects for general linguistics. On the very first page of his doctoral dissertation he notes: "The study of language without linguistic geography is almost impossible", and in his inaugural speech in 1958 he pointed out that "for the correct understanding of the standard language knowledge of the dialects is indispensable". Dialect-lexicography is therefore not a goal in itself, but knowledge of the dialects, made possible by a systematically ordered collection of data, is an important part of the linguistic knowledge in a broader sense.

(b) The three dictionaries are culturally and historically useful, they uncover a culture-historical landscape. Because a word more often than the referent takes root, lexicological research is helpful to cultural history. The large dialect dictionaries reflect the daily life of the dialect-speaking population in the first half of the twentieth century. They also show in what way material and spiritual innovations have been assimilated in the language. In the specifications of the article, encyclopedic information is added, so that a description of the trade itself is also found in the fascicles in which the technical languages are treated.

(c) As reference books, the dictionaries are practically useful. They are helpful to answer questions like: "What does word $x$ signify, and where is it used?" "How does one express y?", etc. In this respect the dictionaries can be compared to other historical dictionaries like the Middelnederlandsch Woordenboek (Middle Dutch Dictionary) or the NED (A New English Dictionary on Historical Principles).

(d) The large dialect dictionaries are also indispensable for the study of social variations in Dutch. Parts I and II (agricultural and other craft terminologies) treat languages with a socially restricted use, but in general the language of the dictionaries reflects a socially and situationally determined variety.

(e) Dialect dictionaries can also have a political function in that they can be seen as a demonstration or as a symbol of the own identity of a group of language-users in contrast to the users of the standard language. Though not intentionally, they can be useful for the codification of a regional standard and therefore for the promotion of literature in the dialect. This 
contribution towards a cultural identity of a certain region forms the main reason for the interest of and the participation by provincial governments in the projects.

\section{Prospects}

Only a close cooperation between the universities, the national scientific organisations and the provincial governments can generate the funding of these three projects. The provincial authorities have discovered that the description of their dialects is a regional cultural issue and they have therefore taken the financial responsibility. The dictionaries are financed following a tripartite agreement: the two national scientific organisations coordinated by the Dutch Language Union, the three universities and the provinces involved (eight at the moment) share the funding, although for different reasons of interest. The procedure is successful. The description of the southern Dutch language area resembles a web in which many threads connect the institutes and the authorities, a web in which, through these threads, communication between the institutes, quality of the work and continuity are guaranteed.

\section{NEW METHODS IN THE TREATMENT OF THE GENERAL VOCABULARY}

\section{Introduction}

One of the most important principles in making a dictionary is not to change methods en route. In the case of the southern Dutch dialect dictionaries a change is however possible, due to the systematic arrangement of the dictionaries and their publication in three parts. All three projects are about to start with part III General Vocabulary, i.e. the vocabulary that is not restricted to professional activities.

Part III is of the utmost importance, not only because a larger public will undoubtedly be interested, but also because it documents the last phase of a long continuum of dialectal varieties of Dutch in the northern part of Belgium onto which the (relatively) recently introduced standard Dutch language is grafted. The three dictionaries are a frame of reference for sociolinguistics in Belgium.

Starting with part III makes it possible to evaluate and improve the methods used so far. Improvement is needed for a number of reasons:

(a) Although the three projects basically have the same plan, they differ inter alia in the way the publications are issued.

(b) The scope of the projects is not in accordance with the financial means, hence there is a need for speeding up the work. 
(c) The geographical representativeness of the investigation is not systematically guaranteed, i.e. it is uncertain whether every existing lexeme for a given concept has at least been recorded once.

(d) Data collection by correspondence, involving questionnaires completed by dialect speakers without any phonetic training, does not guarantee accurate phonetic data. As a result, the phonetic component in the three dictionaries is sometimes secondary (i.e. reconstructed) since it is based on other sources or on specialist literature. This especially is the case for the WVD and for the investigation of the general vocabulary. Moreover, primary and secondary phonetic data cannot be distinguished unless the different sources are presented separately. The phonetic component is also highly redundant with regard to the regular sound phenomena.

(e) The fact that there are two different user groups (namely the general public and specialists) is not always sufficiently taken into account.

(f) The enterprise insufficiently makes use of the advantages of automation.

In his Ph.D. thesis Van Keymeulen (1992) evaluated the approaches and methods of the three dictionaries and tried to formulate new proposals regarding the methods of collection and publication. These new proposals were summarized in a report (Ryckeboer and Van Keymeulen 1992) presented to the REWO. committee (Permanent Overleg Regionale Woordenboeken) (Permanent Consultation for Regional Dictionaries). This committee was instituted in 1990 by the Dutch Language Union in order to ensure the continuation and uniformity of the three projects. The institution of this committee already met the first two points of criticism (a) lack of cooperation and (b) financial difficulties above, since it aims at stimulating cooperation and encourages concerted action for funding.

In what follows there will be focused on the last four points of criticism: (c) geographical representativeness; (d) the reduction of the phonetic component; (e) the two user groups and (f) automation. A last paragraph will dwell on the presentation of the general vocabulary in a systematically arranged dictionary.

\section{Collection of lexical data}

Since dialect vocabulary is characterized by its geographical differentiation, it is of the utmost importance that every existing dialect word is recorded at least once. A further objective which is harder to achieve because the voluntary cooperation of the dialect speakers has to be depended on, is the detection of word boundaries (isolexes), made possible by the abundance of the data.

The following proposals regarding the geographical representativeness of the data collection are especially important for the WVD, because, as Joep Kruijsen pointed out, this project started about ten years later than the others. 
In Ghent, the field work for the general vocabulary has just started, whereas in Nijmegen the collection of the data is considered to be complete, although additional investigations may be needed to fill in geographical gaps. The proposals pertain to field work in different phases:

(a) Establishment of an inventory of concepts on the basis of:

(i) the Hallig-Von Wartburg system (adapted by Corry Frissen);

(ii) a systematic reorganization of the existing alphabetical dialect dictionaries;

(iii) systematic inventories of the standard language; and

(iv) older questionnaires.

(b) Oral investigation by the staff through a network of control points

The Flemish territory (in its dialectological sense, see annex A for the map) was divided into lexical areas on the basis of the existing knowledge of the geographical word patterns. One control point was selected for each of these areas (plus six urban points, plus some additional points in order to have a regular pattem). The inventory of concepts is tested in a discussion group of dialect speakers in order to discover the proportion of dialecticity (i.e. lexical contrast with the standard language) and heteronymity (i.e. the existence of geographically differentiated dialect lexemes). Emphasis is put on the lexical/semantic contrast with the Dutch standard language and on geographical differentiation. The field work aims at reducing the initial inventory and at guaranteeing the geographical representativeness. The dictionaries of the dialects of Brabant and Limburg try to ensure the geographical representativeness by incorporating the local amateur dictionaries also.

(c) Large-scale investigation by correspondence

The questionnaires for a large-scale investigation by correspondence are based on the results of the oral investigation. Only the concepts for which the dialectal lexemes show geographical differentiation, are accounted for in the large-scale investigation.

\section{Two user groups: the general public and specialists}

Before the methods of lemmatizing and publishing the data are discussed, it is necessary to dwell on the users the dictionaries are aimed at. Joep Kruijsen pointed out that the dictionaries meet both a scientific and a social demand, which implies that the needs of both the general public and specialists are to be accounted for. In both cases it is taken for granted that both user groups have a good knowledge of standard Dutch. 


\section{Lemmatizing the data}

The main task of the editor is lemmatization, i.e. grouping together the dialect words that go with lexically relevant concepts. In the tradition of these three dictionaries the term lemma is used for the whole of a dictionary article, not for the headword. The main task for the lexicographer is to ascertain the way the dialect speakers categorize reality. This is achieved by field work and by close analysis (comparing) of the answers to the questions in the questionnaires. The focus of this paragraph, however, will be on the entry forms of the dialect words and on the consequences of the reduction of the phonetic component.

As Joep Kruijsen already indicated, the dictionaries use the "Dutchified" forms of the dialectal lexemes as entries. This means that all phonological and morphological particularities of the dialectal lexemes are replaced by their standard Dutch pendants. This technique is the only possible way of representing entry forms in regional dictionaries that cover many related but different dialects. This technique, however, may put a strain on the dialectspeaking user.

The lexicographer's hope that a dialect speaker will find back "his/her" word in the dictionary, is based on the assumption that a dialect speaker is able to abstract from his/her sound system to the standard Dutch sound system as represented in Dutch orthography. This implies that the dictionary user is considered to have absorbed two related, but different sound systems: the dialectal sound system, and the sound system (as represented in orthography) of the Dutch standard language. In the mind of the dialect speaker there are intuitive sound rules that relate to the two sound systems. They come into existence in that part of the vocabulary that shows no contrast between dialect and standard language, and can be transferred to the contrastive part of the vocabulary.

In standard Dutch, for example, the [œy] sound (written ui) occurs in many high-frequency words (the sound is so to speak "panlexical"), which also occur in the Western Flemish dialects, where the Dutch [œy] sound is represented by the [y] sound (written uu); e.g. Dutch [œyt] <uit> - West-Flemisch [yt] <uut>. Hence the intuitive rule "dialect [y] <uu> equals Dutch [œy] <ui>" guarantees that a speaker of West Flemish recognizes in the entry form uit "his/her" dialect word. The rule can be transferred to the contrastive part of the vocabulary. Thus the West Flemish word uuvallig "dirty" can be written in its Dutchified entry form uivallig (a word that does not exist in standard Dutch), without frustrating the dialect-speaking user too much. This method has its flaws, but the system works if only because all the phonological variants of a given dialect word are presented in the dictionary text. Fortunately, the Dutch orthography is highly phonological.

Parts I and II of the dictionaries contain the phonological documentation of all the words. Each of the three dictionaries uses its own home-made phonographic orthography; the Flemish dictionary the broadest one, the Limburg dictionary the narrowest one. This practice will in future be continued for parts I 
and II. However, it often forces the lexicographer to reconstruct, at least partly, the phonological contours of the words according to the (written) clues given by the respondents and the specialist literature. In part III the phonological component will be reduced to the primary data, i.e. data orally collected by the editors themselves and data written down by respondents with a phonetic training. The phonetic data is entered into the database, but is not made available in printed form any more.

Because of this, a way had to be found to "rescue" the phonological component as much as possible and to find a solution for the fact that the "intuitive sound rules", a rather slippery notion, perhaps do not always lead to the identification of a dialect word with its Dutchified form, if only because the intuitive insights into the sound relation between dialect and standard Dutch may differ from person to person.

The reduction of the phonological component in the dictionary text will be compensated by the following measures:

(a) Every dictionary will be preceded by a phonetic/phonological introduction in which the regular sound patterns of all the dialects under investigation will be described.

(b) A set of lexical variants will be introduced next to the Dutchified entry forms whenever the lexicographer fears that the average user will not be able to retrieve a dialect word because the sound relation between dialect and standard Dutch is too obscure. The lack of transparency can be due to a number of reasons:

(i) The dialect word shows an irregular sound pattern.

(ii) A sound relation may be regular but exceptional.

(iii) Several sound changes occur at the same time.

(iv) A sound change affects the consonantic framework of the dialect word.

(v) The affected dialect lexeme does not occur in standard Dutch.

Some examples:

(i) In Eastern Flanders duvel "devil" contains the sound relic [y], hence: Dutchified entry form duivel, lexical variant duvel.

(ii) Kurre "herd", with an intervocalic [d] becoming [r], is regular, but the words affected by the change are of low frequency; hence: Dutchified entry form kudde, lexical variant kurre.

(iii) In voreeuw "harness" several regular sound changes occur at the same time, affecting the consonantic framework; hence: Dutchified entry form gareel, lexical variant voreeuw.

(c) Primary phonetic data will be entered into the database. 


\section{Database and publications}

The published version of the dictionary distinguishes the lexical difference from the standard language. In principle only the data of the control points are taken into account for lexemes that do not show differentiation from standard Dutch or geographical differentiation. So we end up with a database, a scientific text and a dictionary text:

(a) Database

All the data is stored in a database that contains sources, questionnaires, entry forms, lexical variants, phonological information (based on primary phonetic data) and exact location. The database contains interpreted material. The raw material, i.e. completed questionnaires, is kept in the archives.

(b) Scientific text (see annex E)

With the database as basis a text file is generated that contains lemma titles, sources, entry forms, lexical variants, phonological information and exact location. In practice this text file differs from the database, as the data is further interpreted and sometimes even regrouped. This file is made available electronically (on floppy disk or otherwise) and is meant for specialists who want to have detailed information with regard to location and phonetics.

(c) Dictionary text (see annex D)

The dictionary text meant for the general public is the only publication in printed form. The text is based on the mapping of the data of the scientific text. It contains lemma titles, semantic and encyclopedic information, sources, entry forms, lexical variants and globalized indications with regard to frequency and location. It also contains word maps and illustrations.

Thus each dictionary will be issued in two parallel publications: one meant for the general public, the other for specialists. The former serves as a kind of manual for the latter.

\section{Automation}

A major result of the growing cooperation between the three projects is the development of a common computer program that will replace the existing software. The program can cope with all kinds of data that have a questionanswer structure. It is interfaced with a word processor and a cartographic program (MapInfo), in such a way that texts (consisting of lexemes, source indications and place code numbers) and maps can be generated automatically. The databases of the three dictionaries can be combined in order to plot word maps of the whole area of the southern Dutch dialects. 
The program is menu-driven, very flexible and allows for correction procedures in all stages of the input and the lemmatization. Lemmas are automatically generated by putting together the data from different sources by means of references to the questionnaires, question numbers and/or answers.

\section{Systematic arrangement of the General Vocabulary}

The three dictionaries are systematically arranged. For part I Agricultural Terminology and part II Nonagricultural Terminologies a systematic arrangement is relatively easy, as it is possible to divide a production process in different stages. For part III General Vocabulary an overall classification of all the concepts of the dialect-speaking community is needed. The editorial boards of the three dictionaries do not consider it their task to present the definitive structure of the general vocabulary, but rather aim at presenting the lexemes in such a way that it is possible for linguists to investigate conceptual structures. The classification should serve a practical purpose and should in any case be easy for the average user to handle.

In what follows, the principles for solving the assignment problems are presented. The focus will be on the so-called open word classes (substantives, adjectives, verbs, etc.). The closed word classes (adverbs, prepositions, conjunctions, etc.) present specific problems, because the meaning of the lexemes of these classes is more grammatical than representational. For these classes an alphabetical (semasiological) arrangement will perhaps prove to be necessary.

Generally speaking, the dictionaries present the vocabulary of dialect speakers living in agrarian surroundings during the first half of the 20th century. The concepts should be classified in conformity with what Weijnen called "the concrete coherence of things in daily life" as experienced by the dialectspeaking community (Weijnen and Van Bakel 1967: 40). This means that socalled "scientific taxonomies" that classify the external world on the basis of inherent characteristics, can hardly be used. For example, a class "sounds" in which all existing noises are brought together is only of relative value for the dictionaries. Concepts like "to ring" or "to thunder" should no doubt be dealt with in connection with "house" and "weather", if the arrangement in the dictionary is to reflect the way the dialect speakers perceive the coherence in daily life.

A second principle is that of referential coherence per fascicle, i.e. each fascicle should contain the concepts that the user would expect to be there. For instance, although the words for baker and bread are clearly part of the general vocabulary, the lemmas "baker" and "bread" should also figure in the fascicle on bakery, because it is hardly imaginable to issue a fascicle on the terminology of a trade without the words for producer or main product.

Having said that, means have to be found to objectify subjective notions like "concrete coherence" or "things in daily life". If "the concrete coherence of 
things" is to be the guiding principle of the classification of the general vocabulary, the point of departure has to be man himself and his needs. A functional view (what is the use of this?) rather than an ontological view (what is this?) is held. For example, a tomato is a plant but it is eaten by man. Hence, the words for tomato are classified in a class "food" and not in a class "plants".

For the assignment of a given concept to a certain class, the notion of frequency has been introduced in an attempt to objectify intuitions about folk taxonomies. For example, in solving the problem whether chicken is to be an item in the class "birds", "food", or "hatchery" it is considered how frequently chickens are associated with birds, food or the hatchery in the daily life of the average dialect speaker. It turns out that a chicken is not considered a "bird", but belongs to the category "poultry". As there are more people eating chicken than breeding them, the words for chicken should be assigned to the class "food" rather than to "hatchery". However, because chickens are often bred in the countryside, one may consider a cross-reference or even the repetition of the lemma in a class "hatchery", if the referential coherence of a class demands it. Moreover, it turns out that in the same dialect different words are used for the same objects in different situations. In many Eastern Flemish dialects potatoes are called erpels when they are grown, but they become patatten when they are cooked and eaten.

Practice will show whether the above-mentioned guiding principles can cope with all cases. Not every problem can be solved by this functional-frequentative principle. In a number of cases it will be necessary to fall back on scientific taxonomies because no ordering principle from human experience can be given, e.g. wild plants and animals, qualities of character, etc. In any case, if the world of the dialect speaker is to be reflected in the classification of the general vocabulary, these principles seem a good point of departure. Problems can be solved up to some extent by repeating lemmas or by cross-references.

In practice, the classification of the general vocabulary is based on a rearrangement of the already existing classifications of Hallig-Von Wartburg (1952) and of the Woordenboek van de Achterhoekse en Liemerse Dialecten (WALD) (Dictionary of the Achterhoek and Liemers Dialects) (see annex F). Man is placed at the centre of things, and reality is assigned to him in ever broadening circles. Thus the classification of the general vocabulary consists of four major classes: 1 Man; 2 Domestic life; 3 Society; 4 External world. Within each class, the concepts are as much as possible clustered around human needs; hence, for example, in 2 Domestic life the subclasses 2a House; $2 b$ Family life and $2 c$ Food are distinguished. In any case, owing to the elaborate registers (systematic and alphabetical, both on lemma titles and entry forms/lexical variants), the user is in a position to control decisions and correct them if need be. 


\section{Conclusion}

The three dictionaries of the southern Dutch dialects inventory the vocabulary of the oral tradition of the Dutch language in the south of the Netherlands, in Belgium and in the north of France. The project as a whole is a major international and interuniversity undertaking. Owing to the ever closer cooperation between the three editing boards and to automation, an ever better idea of the geographical variety in the southern Dutch language area is obtained. The traditional dialects are disappearing rapidly because of the pressure of standard Dutch and because of the disappearance of the small-scale agrarian culture of which the traditional dialects bear witness to. Large parts of the centuries-old vocabularies of the traditional dialects will not survive into the third millennium. The three dictionaries must be written now or never.

\section{Bibliography}

Hallig, R. and W. von Wartburg. 1952. Begriffssysteem als Grundlage für die Lexikographie. $A b-$ handlungen der deutschen Akademie der Wissenschaften zu Berlin. Klasse für Sprachen, Literatur und Kunst, nr. 4. Berlin: Akademie Verlag.

Ryckeboer, H. and J. van Keymeulen. 1992. Rapport over de lexicografie van de Nederlandse dialecten. Publikatieblad van de Nederlandse Taalunie 13: 46-53.

Schaars, A. 1984 -. Woordenboek van de Achterhoekse en Liemerse Dialecten. Doesburg: Staring Instituut Doetinchem.

Van Keymeulen, J. 1992. De algemene woordenschat in de grote dialectwoordenboeken (WBD, WLD, WVD). Een methodologische reflectie. Unpublished Ph.D. dissertation. University of Ghent.

Weijnen, A. and J. van Bakel. 1967. Voorlopige inleiding op het Woordenboek van de Brabantse Dialecten. Assen: Van Gorcum. 
Annex A: Map of the southern Dutch language area

ALPic Alas Linguistique Picard

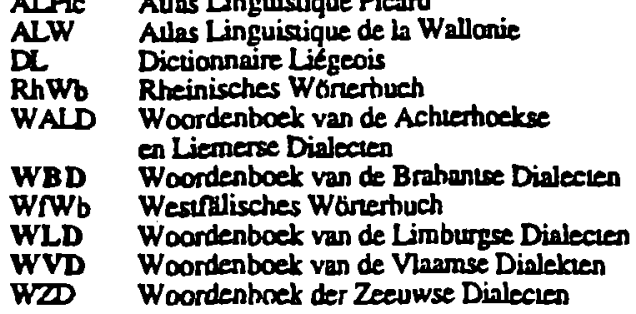

WDP

Dinlekcuen

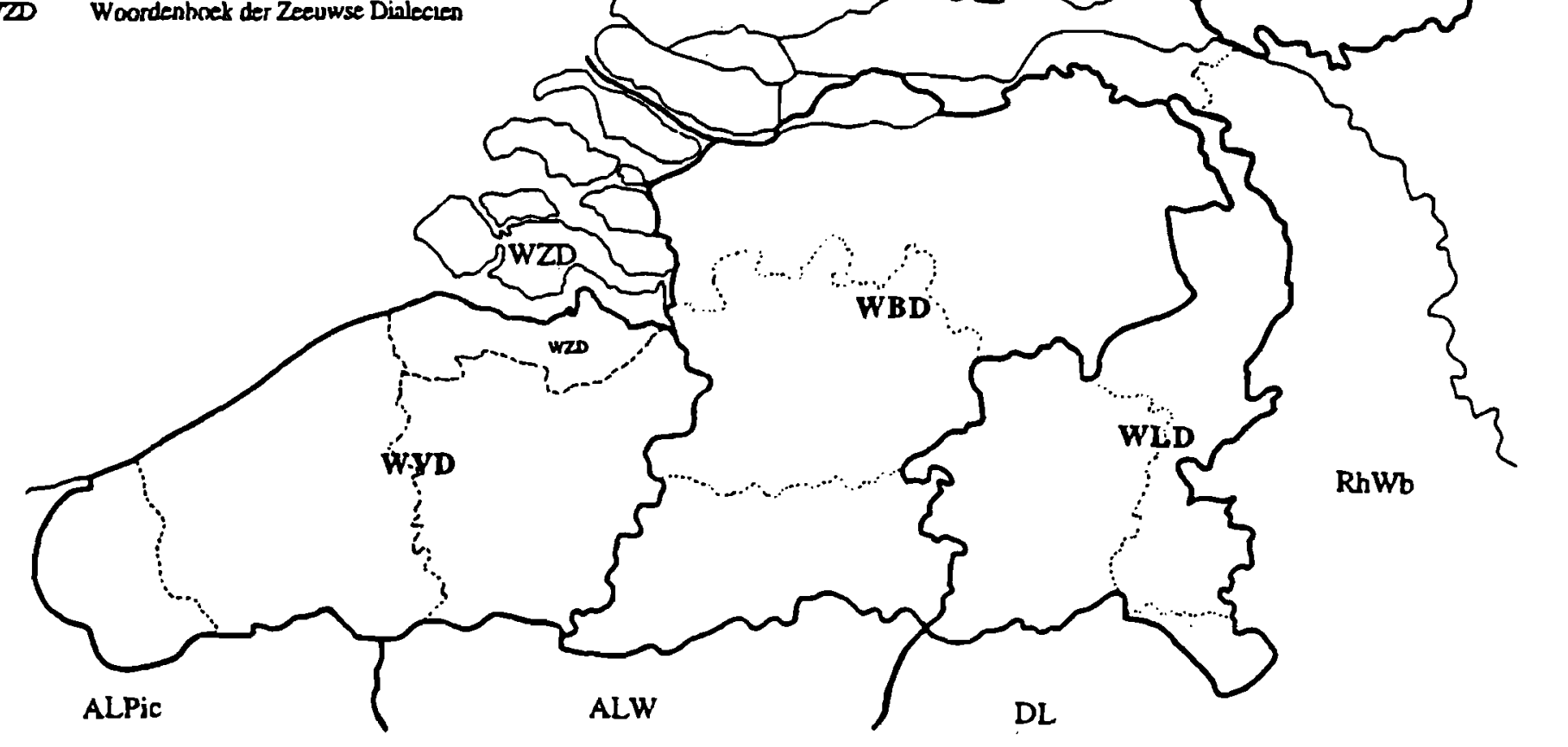


Annex B: A page from the Woordenboek van de Brabantse Dialecten (pt. I, fasc. 1, p. 153)

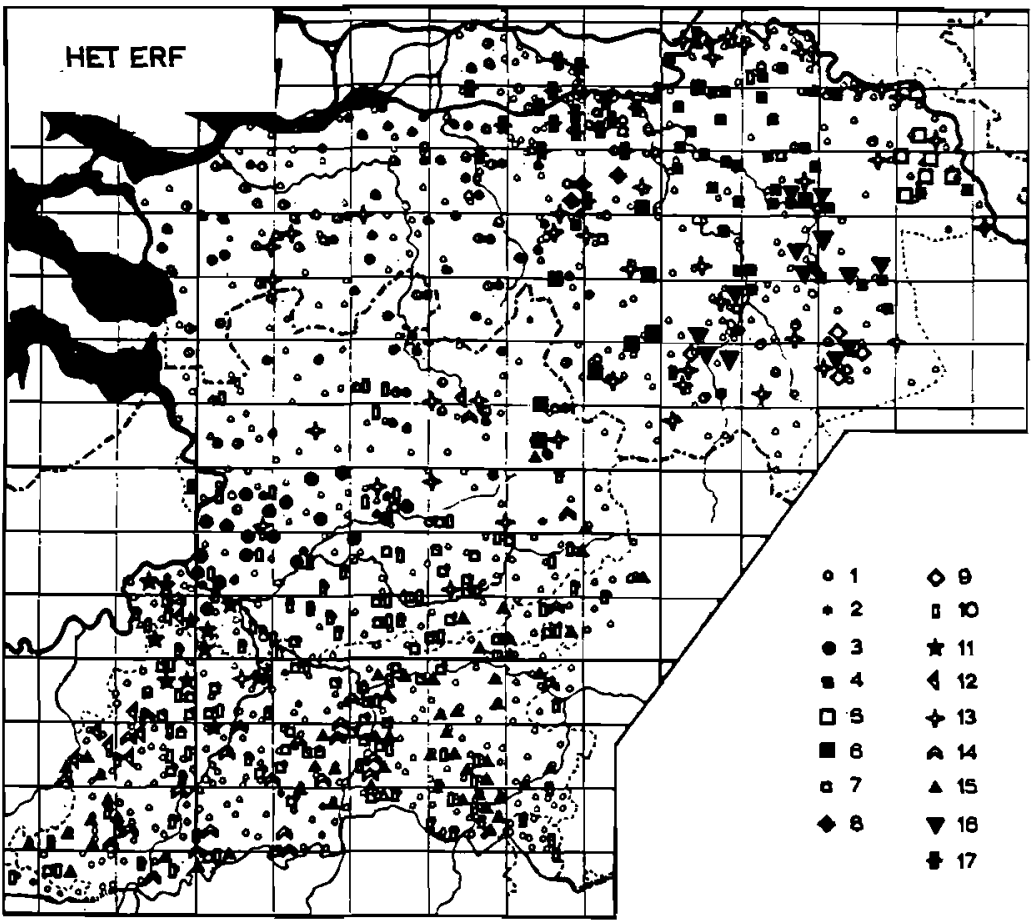

K 240; boerenerf: boermerf, L 114a, 158, 239; werf (krt no. 1): wtrf, K 189, 203. 209, 210, 237, 240, 241, 274, 317; wèf. K 102, 149, 165, 191, 194, L 100, 150, 183; wejorf, K 189; werf. I 57, 78, 79, 118 , K 100a, 101, 101a, 102*, 131, 133a, 133c, $137,146,152,158,158 \mathrm{~b}, 158 \mathrm{c}, 161 \mathrm{a}$ $162 \mathrm{a}, 163 \mathrm{c}, 164 \mathrm{a}, 167,168,176,177$, 182. 182b, 185, 188a, 235, L 93, 152, 158, 239. 241, 242, 259, 260, 261: weErf. K 188a, 209, 212, 237, 240; wderf, K 216a L $91 \mathrm{~b}, 93,99,153,264$; weerf, K 215; wurf, K 151; wart. I 78a,79, K 102a. $145 \mathrm{a}, 153,0153,157,173 \mathrm{a}, 173 \mathrm{~b}, 174$ $175 a * 188,188 a, 203,224,227,248$ : warf, I 57, 78, K 151, 157, 173, 173*, $174,175,175 a, 176,177 b, 188,225$ : waerf, hs Renders L 226; waaref, Leopold, gegeven voor 's-Gravenmoer-Dongen; wetrf, gegeven voor de lage Maaskant, Elemans; wärsf, wärof, De Bont; werf, Goossenaerts: werft (krt no. 2): werft, K 182, 183, 184a, 207, 210, 232, 240, 268, 288, 330; werth, K 184, 191, 192, 193a, 204, 291: wer/t, K 124a, 125, 125a, 126, $127,127 \mathrm{a}, 129 \mathrm{a}, 130,148,149,155$.
$158 \mathrm{~b}, 161,161 \mathrm{a}, 162,163,163 \mathrm{c}, 164$, $179 \mathrm{a}, 180,181,182,182 \mathrm{a}, 183 \mathrm{~b}, 184$, $184 a, 193 a, 194,195,197,198,207,210$, 211, 237, 246; wetrft, K 178*, 184a, 201, $211,237,273,287$; wedrft, K 190, 191, L 232; wéerft, K 180; waertt, K 201, 208, 231: wruft, K 151, 152; wörft, K 268; waarft, K 176, 177b, 180, 226, 245; warft, K 245, 246; wer $f t$, Corn. Vervl.; boerenwerf: boevewerf. Goossenaerts; boerenwerft: boevequrft, K 152, Weijnen EV 8; voorhoofd (krt no. 3): vurft, K 252, 254, $256,285,287,288,291,296$; v8rft, K 262; veurft, $\mathrm{K} 281$; verfi, $\mathrm{K} 252$; voert $t, \mathrm{~K} 286$; vurraft, K 246, 249, 250, 255, 268, 282, 283, 286, 296, 320; vormaft, K 267; veuruft, K 287; vurf. K 281; vörft, uitspr. vörratt, de open plaats welke vóor de boeve ligt (...) de achterplaats heet ook vör $t h$, Corn. Vervl.; misse (krt no. 4): misso, K 149, L 91b, 99, 100, 144, 145 , $145 a, 146,147,148,149,150,151,152$, $153,157,177,177 \mathrm{c}, 178,178 \mathrm{a}, 179,180$, $180 \mathrm{a}, 180 \mathrm{~b}, 180^{* *}, 181,182,183,185$, 189, 200, 201, 202, 203b, 205, 206, 208. 208a, 233, 244, 256: misss, grond voor de 


\section{Annex C: A page from the Woordenboek van de Limburgse Dialecten (pt. I, fasc. 5, p. 131).}

\author{
Kaart 71. BRAAM \\ (Rubus fruticosus L.) \\ , braam \\ - braamdoom \\ - doom
}

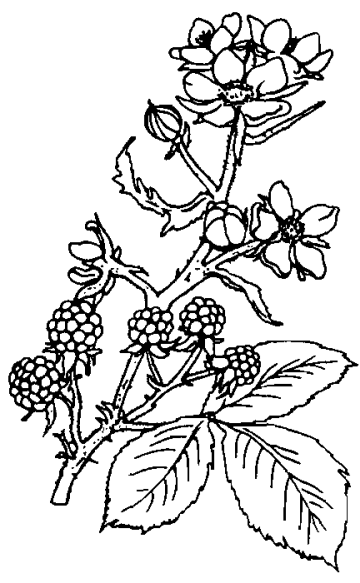

AB. 64. Bram (Rubus fruticosus L.)

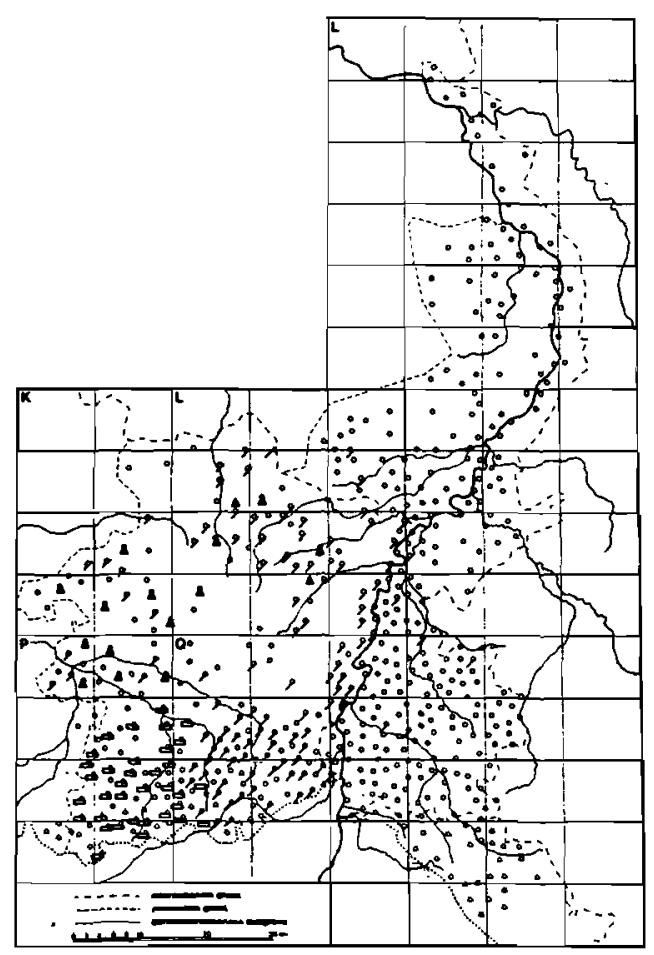

bro.ndz8.n P 187, 188; bryq.n- P 121, 184; brondōn P 176, 178; brendī'n P 115, 173, 179. 180, 182, 218, 219: brendyan $P$ 174, 175; brendy.en P 224, 227; bro.gdye.n P 220, 223; doornstrulk: dērastrȳ.k L 423; djp.nastruk $\mathrm{P}$ 186; doorns: dōras K 316; dō.ros K 353, 357. 359, L 315; do.rasa L 354; dera Q 13; dẹra L 316: dēra L 362, 367; déan L 413; dien K 361; di" Q.n P 57; dt’n P 51; djo.n P 49; dje.n P 53: dyana $P$ 45; braamberenstruik: bremberastruk L 214, 214a, 215, 217, 245b, 246a; brameltenstruik: brōmoliastryk L 291; bramenstruik: bromastruak L 318b; brioma- L 318b; braam. buttenhout: brembytenhät K 278 (hut is struik); berenstruik: bërastruk P 214; tuinsteekselen: turtieksals Q 113 (tuin is hier ,heg"); kretsdoorn: krezjēn P 55: kre.dzdjo.n Q 2; doornebraak: $\mathrm{P}$ 46; brakkdoorns: brāgdjō.n $\mathrm{P}$ 46;

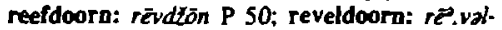
djo.n P 52.

\subsubsection{BRAAMBESSEN (kaart 72)}

(JG $1 \mathrm{~b}$ (gedeeltelijk), 1c, 2c)

[Als aanvulling op de vraag die in het voorgaan- de lemma is behandeld werd ook geïnformeerd naar de benamingen van de vrucht van de braamstruik.]

braamberen: brombēra K 357, 358, P 44, 46, 49, 50, 51, 57; brọm- L 288, 288a; brom- L 164, 192a, 210, 214, 214a, 216a, 217, 244d, 246b; brem-K 316, 318, 357, 359, P 45; bremP 48; brombēr L 286, 314, 318, 318b, 353, 374, P 54; brown- L 288a; brombē.n K 361, L 282. $312,313,314,315,316,318,352,353,354$, $355,413, Q$ I, 2a, 74; brō.m-K 360, P 51, 56, Q 2; brum- L 286; bruam- L 414; brámbęra L 246. 246c, 249; brom- L 159a. 163, 164. 192. $192 \mathrm{a}, 209,210,212,214,214 \mathrm{a}, 215,215 \mathrm{a}, 216$, $217,245,245$ b, 246, 246a, P 108a, 115, 172; brō.m- Q 241: brẹm- L 244c. P 45; brum- L 247. P 47; brombēra L 214, 250, P 113; brömbeiro P 176a; brom- P 113, 115, 172, 173. 176; brom- P 181; brum- P 47, 48, 176; bro.mbeli.ro P 119. 120 121, 177a. 178, 184, Q 1, 78; brämbejara P 184; brómbiara L 289; brq.mbia.ro Q 152; bro.m-P 46, 117, 119, 188, Q 2a, 73, 156; brem- K 316; brum- L 317, 417; bro.mbiam L 416; bro.mbi.m L 415; brombie.r? P 186; brōmbicra P 187; bro.m-P 192, Q 159. 


\section{Annex D: A page from the Woordenboek van de Vlaamse Dialecten, the Dic- tionary Text (pt. III General Vocabulary, fasc. 1 Birds, p. 47)}

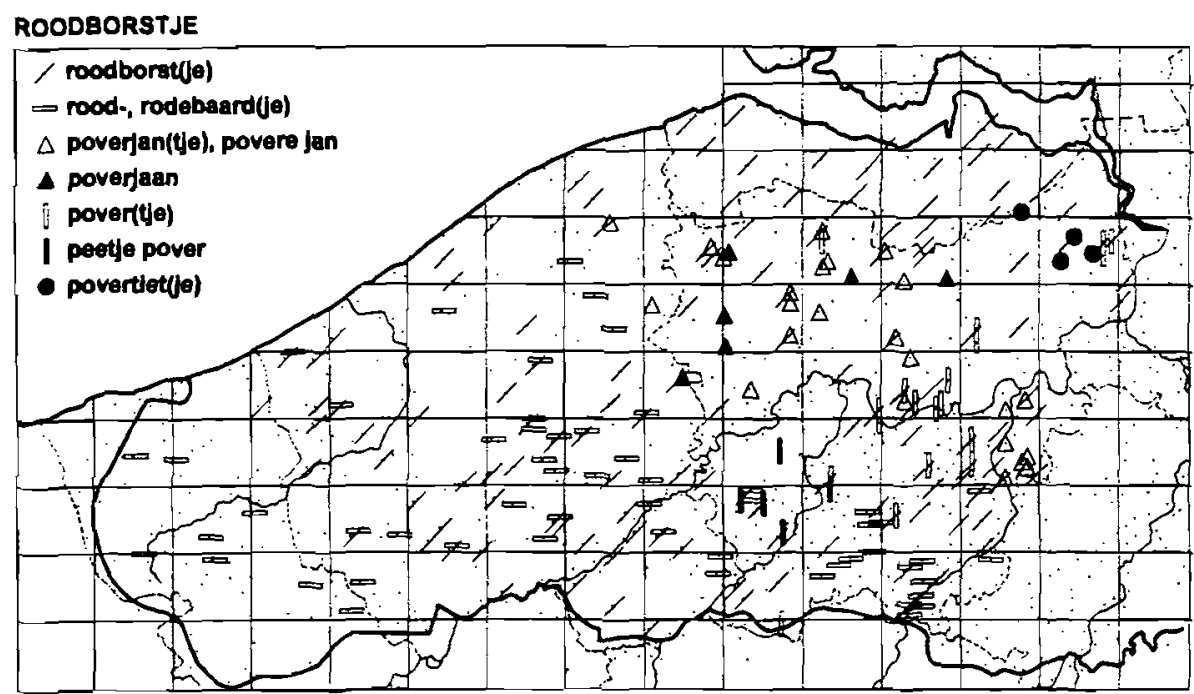

winterkneutje : • Eeklo.

winterkoning(-kje) : spor. OV zuid beoosten Schelde, Wasal. en OZV; zeldz. Veurne-Ambacht, ook Stene, Gits, Zuidzande en Gent.

-s por. WV, OZV en OV; zeldz. WZV. $\mathrm{Wdb}$ : Joos : winterkeuninksken. $\mathrm{T}_{8}: \mathrm{Bij}$ dragen Deinze : winterkeuninkske, omg. Deinze. Div : Avifauna : winterkeuninkske, OZV. Dialect OZV : winterkeuninkske(n), -koninkje(n). Nederlandse Vogelnamen : winterkeuninkske, OZV.

winterpover : • Kloosterzande.

wipstaartje [urustaartje] : Poelkapelle.

\section{ROODBORSTJE}

Het roodborstje (Erithacus rubecula) is cen klein, gedrongen vogeltje met oranjerode borst. Men ziet het in parken en tuinen. 's Winters komt het soms bij de mensen om roedsel bedelen. Zie afb. 12 .

WVD 66r (1995), 201 ; WVD 66 (1995), 102 ; N 9 (1961), 24 ; Materiaal Menschaert (1991), 83 ; Vandecasteele (1978), 84 ; Wieleweal (1952), 250 ; DC 6 (toegift)
(1938), 28; ZND 34 (1940), 72 (toegift). Volk en Taal 3 (1890), 170 ; Annalen Land van Wass 73 (1970), 114; Duumpje 13 (1987), 17 ; Bijdragen Deinze 55 (1988), 266. Dialect OZV (1982), 179 ; Nederlandse Vogelnamen (1995), 192.

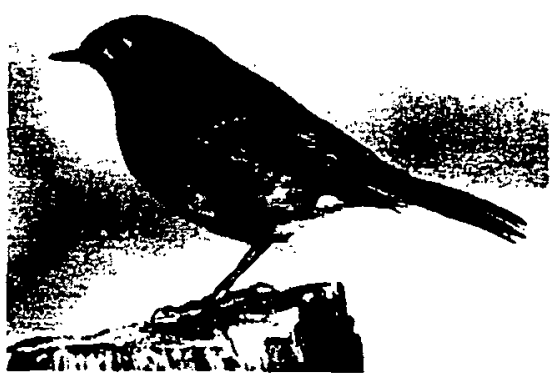

Afb. 12. Roodborstje.

arme jan : Ieper.

peetje pover : freq. OV zuid tussen Leie en Schelde, ook Dikkelvenne.

peetje povers [peetje pofers] : Kruishoutem. 
Annex E: A page from the Woordenboek van de Vlaamse Dialecten, the Scientific Text (pt. III General Vocabulary, fasc. 1 Birds, p. 47)

winterkneutje: ZND 34: I 158. winterkoning: WVD 66: I 166; N 9: I 179, N 82; wint arkeuning: DC 6: I 143; wintarkeuningk: DC 6: I 115. winterkoninkje: WVD 66: H 51, H 84, I 106, I 116, I 140, I 143b, I 208, N 33, O 199; N 9: O 46; Wielewaal: I 175, O 37, O 111, O 207; DC 6: I 107, I 109, I 112, I 116c, I 125a, I 138, I 139, I 142, I 144a, I 162; ZND 34: H 1, H 2, H 9a, H 12, H 21, H 29, H 69, H 84, H 110, H 113, I 155, I 175, I 183, I 193, I 213, I 241, I 250, I 252, I 258, N 28a, N $35, N 36, N 38, N 67, N 69, N 83, N 131, N 141, O 14, O 36, O$ 38, O 47, O 86, O 130, O 144, O 181, O 208; wient arkeeningkskan: ZND 34: O 150, I 264; wient arkeuniengksj a: ZND 34: N 74; wient arkeuniengsja: ZND 34: H 24; wint arkeuneingkska: ZND 34: O 82; winterkeuningkskan: ZND.34: 0 216; wint arkeuningsja: WVD 66M: H 18; $N$ 9: $N$ 26; wintarkeuningska: ZND 34: $N$ 38; wint arkeuningsk an: WVD 66M: I 241; ZND 34: I 164, I 176;

wint arkeuningskie: ZND 34: $\mathrm{N}$ 38; wintarkeuningstjie: ZND 34: $\mathrm{H} 36$; wint arkooningskan: N 9: I 264; wintarkaningska: ZND 34: I 218. winterpover: DC 6: I 116c. wipstaartje wupstaartie wupstertja: Vandecasteele: N 31.

Annex F: Classification of the General Vocabulary

1. Man

1a Body

1b Clothing

1c Internal reality (mind, emotion ...)

2. Domestic life

2a House

2b Family life

2c Food

3. Society

3a Societal behaviour

3b School

3c Religion

3d Amusement

4. The external world

4a The material world

4b Plants and animals

4c The a priori (time, space, form, ...) 